\title{
Is it easy to clinically distinguish inflammatory arthritis of bacterial origin from monoarthritis attacks of gout disease?
}

\author{
Bakteriyel kaynaklı enflamatuvar artriti gut hastalığının monoartrit ataklarından \\ klinik olarak ayırt etmek kolay mıdır? \\ O. Şahap Atik, MD., ${ }^{1}$ Yılmaz Ergişi, MD., ${ }^{1}$ Tacettin Ayanoğlu, MD., \\ Mehmet Ali Tokgöz, MD., ${ }^{1}$ Erdem Aras Sezgin, MD., ${ }^{1}$ Pınar Uyar Göçün, MD. ${ }^{2}$ \\ 'Department of Orthopedics and Traumatology, Medical Faculty of Gazi University, Ankara, Turkey \\ ${ }^{2}$ Department of Pathology, Medical Faculty of Gazi University, Ankara, Turkey
}

\begin{abstract}
Acute monoarthritis is a common situation in orthopedic emergency where the patient presents with typical inflamed joint. It is hard to clinically distinguish inflammatory arthritis of bacterial origin from monoarthritis attacks of gout disease. If these two situations, which are the most common causes of acute monoarthritis, are misdiagnosed, outcomes might be catastrophic and costly. Synovial fluid analysis is the most reliable method for confirming the diagnosis although it might not always lead to definitive diagnosis. If there is clinical suspicion for crystal arthropathy, repeated examinations may provide benefits for confirming the diagnosis.
\end{abstract}

Keywords: Crystal arthropathy; gout arthritis; monoarthritis; septic arthritis

Gout is a disorder in the purine metabolism that causes recurrent arthritis attacks, chronic arthropathy, tophi deposition, and renal disease. It is hard to clinically distinguish inflammatory arthritis of bacterial origin from monoarthritis attacks of gout disease. ${ }^{[1]}$ The prevalence has risen significantly in the last few decades due to the shift in lifestyle and diet. In England, the rate increased from $0.3 \%$ in 1970 to $1 \%$ in $1990 .{ }^{[2]}$ Data between 2000 and 2005 show a rate of $1.4 \%{ }^{[3]}$ Same trend could be observed in USA, especially in the older male population as the rate increased drastically from $2.1 \%$ in 1990 to $4.1 \%$ in $1999 .{ }^{[4]}$ It is more common in males than females. Advanced age and dietary preferences are known to increase the risk. Particularly high consumption of meat, sea food and beer, which are rich in
$\ddot{O Z Z}$

Akut monoartrit, hastanın tipik enflamasyonlu bir eklemle başvurduğu, ortopedik acillerde sık görülen bir durumdur. Bakteriyel kaynaklı enflamatuvar artriti gut hastalığının monoartrit ataklarından klinik olarak ayırt etmek zordur. Akut monoartritin en sık nedenleri olan bu iki duruma yanlış tanı konulursa sonuçlar felakete yol açabilir ve maliyetli olabilir. Sinoviyal sıvı incelemesi tanıyı doğrulamada en güvenilir yöntem olsa da her zaman kesin tanıya yönlendirmeyebilir. Eğer klinik olarak kristal artropati şüphesi varsa tekrarlayan incelemelerin tanı koymada faydası olabilir.

Anahtar sözcükler: Kristal artropati, gut artriti; monoartrit; septik artrit.

purine content, have been described as important risk factors. ${ }^{[5,6]}$ Although chronic hyperuricemia is known to be the most important risk factor, gout develops in only a small fraction of the population with hyperuricemia. ${ }^{[7]}$ Similarly, the serum urate concentration might be observed as normal during an acute attack. ${ }^{[1,7]}$ Chronic diseases like hypertension, hyperglycemia, hyperlipidemia, and obesity are also associated with increased risk of gout along with the usage of drugs such as diuretics and low-dose aspirin. ${ }^{[8]}$

The patient presents with typical inflamed joint which is warm, swollen, erythematous, and tender. Under such clinical situation, differentiating the two most common causes, septic arthritis and crystal

- Received: October 18, 2016 Accepted: October 25, 2016

- Correspondence: O. Şahap Atik, MD. Gazi Üniversitesi Tıp Fakültesi Ortopedi ve Travmatoloji Anabilim Dalı, 06500 Beşevler, Ankara, Turkey. Tel: +90 312 - 2025528 Fax: +90 312 - 2129008 e-mail: satikmd@gmail.com 
arthropathy, is crucial and poses a challenge to the clinician as septic arthritis may develop irreversible damage to the joint. Synovial fluid (SF) analysis is the most reliable method for confirming the diagnosis. Care should be taken, as these arthritides can coexist and presence of crystal does not always exclude bacterial arthritis. ${ }^{[9]}$

\section{CASE REPORT}

A 44-year-old male patient presented to our outpatient clinic for the first time with the chief complaint of ongoing pain on the left knee for the last two months. He described five attacks of monoarthritis in the same joint during 2010 to 2014, with six to twelve months in between. During the monoarthritis periods, he had pain, limited range of motion, swelling, and localized warmth. Upon his hospital admissions, this inflammatory condition had been thought to be of bacterial origin and he received antibiotic treatment. The latest attack, which started two months before his presentation to our clinic, had shown no sign of regression despite the use of antibiotics.

On physical examination, there was swelling, localized warmth, tenderness, and limited range of motion on the left knee. Blood chemistry screen resulted all within reference limits including the serum uric acid levels. Leukocytosis was recorded on cell count and acute phase reactant levels were high. Arthrocentesis showed a cloudy yellow SF which was then analyzed. Gram staining showed increased leukocytes but no bacteria and culture result was also negative. Synovial fluid cell count showed increased leukocytes and in SF chemistry analysis, a glucose level slightly lower than in blood was observed. Synovial fluid microscopy performed by pathologists showed no sign of crystals.

Conventional radiography showed no pathologies other than chronic findings of chondromalacia patella. Magnetic resonance imaging (MRI) showed apparent effusion, synovial hypertrophy, and high contrast accumulation suggesting septic arthritis.

Culture with negative results was associated with empiric antibiotic treatment that had been going on for the last two months and reason for the clinical situation was thought to be of bacterial origin. A second arthrocentesis was made and SF culture did not grow any bacteria. Deoxyribonucleic acid strain analysis was preformed and it was positive for Leptothrix spp. and Schlegelella aquatica spp. although these results were thought to be related with contamination. Patient received empiric antibiotic treatment. The patient was observed to be responding well to the treatment and symptoms started to fade.
However, 20 days after the empiric antibiotic treatment, the patient was admitted to our clinic once again with the same symptoms he had at his first presentation. Arthrocentesis was performed and joint fluid was analyzed. The fluid was macroscopically cloudy and yellow. Microscopic analysis was performed by rheumatologists and pathologists. Rheumatology department reported thin, needleshaped crystals at direct microscopic view (Figure 1).

Pathology analyzed cytospinned and Diff Quik (DQ; Dade Behring-Switzerland) stained preparation under polarized light and also reported narrow, needle-shaped, mostly extracellular, negative birefringent monosodium urate (MSU) crystals which were very bright against the dark background (Figure 2, 3), and gout arthritis was diagnosed. There were structures which were thought to be bacteria with coccoid morphology and many leukocytes on the sample but blood and SF cultures did not grow any bacteria.

The patient responded well to the colchicine and indomethacin treatment he received and was discharged. A written informed consent was obtained from the patient.

\section{DISCUSSION}

Acute monoarthritis is a common situation in orthopedic emergency. There are difficulties in differentiating the two most common causes of acute monoarthritis; septic arthritis and crystal induced arthritis. It is extremely crucial to distinguish these because septic arthritis on one hand may lead to irreversible damage to the joint and gout arthritis on the other hand may receive inappropriate treatment which leads to increased cost and discomfort due to

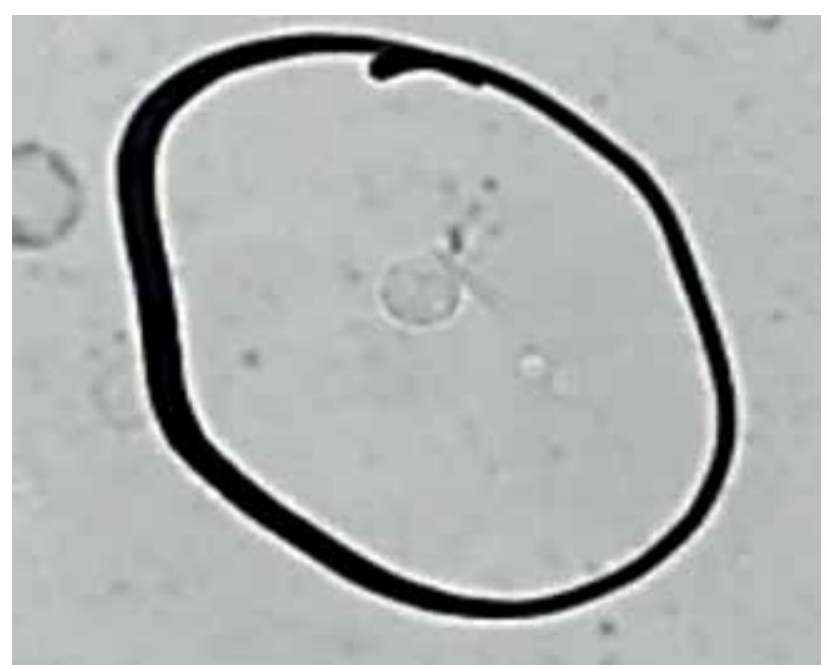

Figure 1. Direct microscopy. 


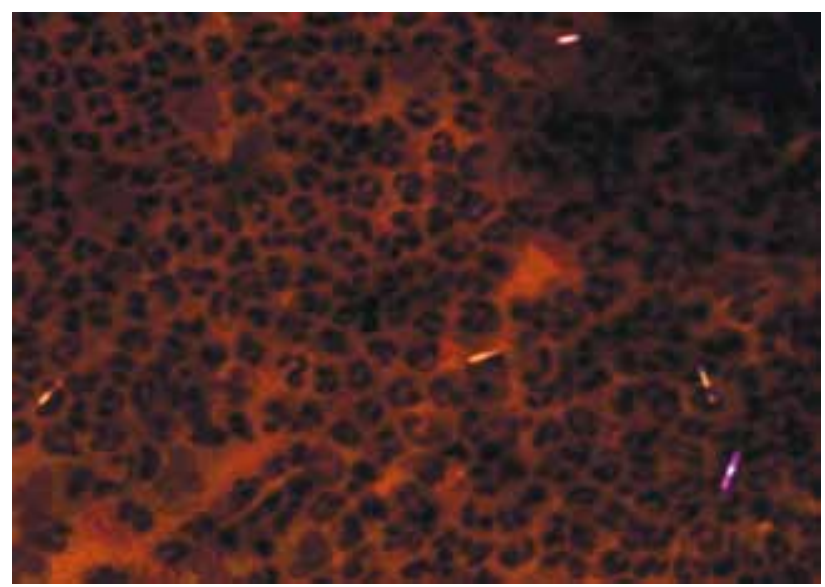

Figure 2. Diff Quik stained preparation under polarized light, 600x magnification.

continuous admissions to hospital with no sign of recovery. Many reports show that misdiagnosis in these arthritides is costly. ${ }^{[1,11]}$

Gout arthritis with no treatment usually goes into remission within few days. Many patients suffer a second attack most commonly within six months to two years after the initial attack.

Only two thirds of patients have abnormal levels of serum uric acid during an acute attack..$^{[12,13]}$ There is evidence that other blood chemistry work is of little value for diagnosis. ${ }^{[14]}$ Urine uric acid is also usually observed within normal range during an arthritis attack.

According to the recommendations by European League Against Rheumatism and the American College of Rheumatology published in 2015, SF analysis is the main diagnostic method for gout arthritis. $^{[15]}$ Observing monosodium urate (MSU) crystals in SF samples is solely enough for diagnosis. They appear as narrow, needle-shaped crystals which are very bright against a dark background and can be seen intracellular or extracellular under the microscope. Although they can be observed with standard microscope, their negative birefringent properties that could be seen under polarized microscope are characteristic, which enables their discrimination from other crystals. Pseudogout, which is calcium pyrophosphate crystal deposition, must be considered in differential diagnosis. Calcium pyrophosphate crystals are rod or rhomboid shaped polymorphic crystals which are mostly intracellular and smaller than MSU crystals. Most of them do not show birefringent properties but some can be birefringent with positive elongation. It should be kept in mind that crystals formation

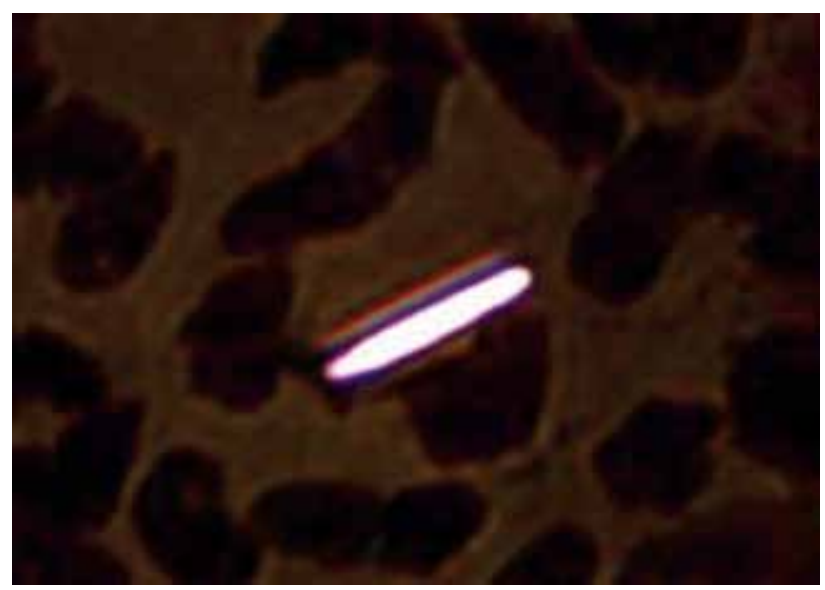

Figure 3. Crystal showing negative birefringence under polarized light, 1000x magnification.

and resolution depend on the $\mathrm{pH}$ and temperature; after aspiration the fluid should be examined rapidly at room temperature. ${ }^{[16]}$ Cytospin and Diff-Quick (Dade Behring-Switzerland) stain technique has high sensitivity and specificity.

There is interobserver and intraobserver error in the assessment of cells and identification of crystals in $\mathrm{SF}^{[17]}$ It is reported in several studies that some of the patients with gout were negative for MSU crystals on initial SF examination, and then were found to be positive if the microscopic examination was repeated with the same specimen. ${ }^{[18,19]}$ If there is clinical suspicion for crystal arthropathy, repeated examinations may provide benefits on diagnosis.

As the whole clinical picture of gout arthritis might mimic septic arthritis or there is possibility of coexistence, analysis for bacteria detection must be performed.

Radiography is not useful in diagnosis during an acute attack. ${ }^{[20]}$ Although findings such as soft tissue swelling and effusions might be present, they are not specific. ${ }^{[21]}$ Ultrasound lacks ionizing radiation and due to being relatively cheap, is easy to access. But its sensitivity is lower than MRI showing joint inflammation and structural changes. ${ }^{[22]}$ Its biggest limitation is its operator-dependent nature. On patients with gout arthritis, it may show an abnormal hyperechoic band over the superficial margin of the articular hyaline cartilage, defined as double contour sign. ${ }^{[23]}$ Although its use in rheumatoid arthritis has been studied thoroughly, there are limited number of studies specific to its use in gout arthritis. There are no internationally recognized descriptions and definitions of pathology seen in gout on US. ${ }^{[22]}$ The standardization and validation of US abnormalities 
are necessary for advancing its use as a reference imaging method for diagnosis of gout arthritis. ${ }^{[24]}$ Magnetic resonance imaging is an excellent method for viewing synovium, cartilage, soft tissue, and bone. Limitations are its high cost, poor accessibility and long scanning time. It may show bone marrow edema which is uncommon in gout and if seen, should raise the question of infection. ${ }^{[25]}$

Rest, local cold application to the affected joint, colchicine, non-steroidal anti-inflammatory drugs, or both is recommended for treatment of the acute attack. Urate lowering therapy is indicated for patients with recurrent gout attacks, chronic arthropathy, and tophi. Systemic or intra-articular steroids might be preferred for patients with impaired renal function. Patient education has an outstanding value for the management of gout. Slow weight reduction, avoidance of beer, meat, and sea food are recommended.

In conclusion, it is hard to clinically distinguish inflammatory arthritis of bacterial origin from monoarthritis attacks of gout disease. These two conditions are very common and easy to misdiagnose. In such a scenario of misdiagnosis, results might be catastrophic and costly.

\section{Declaration of conflicting interests}

The authors declared no conflicts of interest with respect to the authorship and/or publication of this article.

\section{Funding}

The authors received no financial support for the research and/or authorship of this article.

\section{REFERENCES}

1. Atik OŞ. Do not treat the radiograph, treat the patient! Eklem Hastalik Cerrahisi 2015;26:125.

2. Harris CM, LloydDC, LewisJ. The prevalence and prophylaxis of gout in England. J Clin Epidemiol 1995;48:1153-8.

3. Annemans L, Spaepen E, Gaskin M, Bonnemaire M, Malier V, Gilbert T, et al. Gout in the UK and Germany: prevalence, comorbidities and management in general practice 20002005. Ann Rheum Dis 2008;67:960-6.

4. Wallace KL, Riedel AA, Joseph-Ridge N, Wortmann R. Increasing prevalence of gout and hyperuricemia over 10 years among older adults in a managed care population. J Rheumatol 2004;31:1582-7.

5. Grassi W, De Angelis R. Clinical features of gout. Reumatismo 2012;63:238-45.

6. Choi HK, Atkinson K, Karlson EW, Willett W, Curhan G. Alcohol intake and risk of incident gout in men: a prospective study. Lancet 2004;363:1277-81.

7. Doghramji PP, Wortmann RL. Hyperuricemia and gout: new concepts in diagnosis and management. Postgrad Med 2012;124:98-109.
8. Hunter DJ, York M, Chaisson CE, Woods R, Niu J, Zhang Y. Recent diuretic use and the risk of recurrent gout attacks: the online case-crossover gout study. J Rheumatol 2006;33:1341-5.

9. Yu KH, Luo SF, Liou LB, Wu YJ, Tsai WP, Chen JY, et al. Concomitant septic and gouty arthritis--an analysis of 30 cases. Rheumatology (Oxford) 2003;42:1062-6.

10. Ho G Jr, DeNuccio M. Gout and pseudogout in hospitalized patients. Arch Intern Med 1993;153:2787-90.

11. Radcliffe K, Pattrick M, Doherty M. Complications resulting from misdiagnosing pseudogout as sepsis.Br Med J (Clin Res Ed) 1986;293:440-1.

12. McCarty DJ. Gout without hyperuricemia. JAMA 1994;271:302-3.

13. Urano W, Yamanaka $H$, Tsutani $H$, Nakajima $H$, Matsuda $\mathrm{Y}$, Taniguchi A, et al. The inflammatory process in the mechanism of decreased serum uric acid concentrations during acute gouty arthritis. J Rheumatol 2002;29:1950-3.

14. Shmerling RH. Synovial fluid analysis. A critical reappraisal. Rheum Dis Clin North Am 1994;20:503-12.

15. Neogi T, Jansen TL, Dalbeth N, Fransen J, Schumacher HR, Berendsen D, et al. 2015 Gout classification criteria: an American College of Rheumatology/European League Against Rheumatism collaborative initiative. Ann Rheum Dis 2015;74:1789-98.

16. Gálvez J, Sáiz E, Linares LF, Climent A, Marras C, Pina MF, et al. Delayed examination of synovial fluid by ordinary and polarised light microscopy to detect and identify crystals. Ann Rheum Dis 2002;61:444-7.

17. Swan A, Amer H, Dieppe P. The value of synovial fluid assays in the diagnosis of joint disease: a literature survey. Ann Rheum Dis 2002;61:493-8.

18. Redon J, Mancia G, Sleight P, Schumacher H, Gao P, Pogue J, et al. Safety and efficacy of low blood pressures among patients with diabetes: subgroup analyses from the ONTARGET (ONgoing Telmisartan Alone and in combination with Ramipril Global Endpoint Trial). J Am Coll Cardiol 2012;59:74-83.

19. Yuan S, Bien C, Wener MH, Simkin P, Rainey PM, Astion ML. Repeat examination of synovial fluid for crystals: is it useful? Clin Chem 2003;49:1562-3.

20. Rousseau I, Cardinal EE, Raymond-Tremblay D, Beauregard CG, Braunstein EM, Saint-Pierre A. Gout: radiographic findings mimicking infection. Skeletal Radiol 2001;30:565-9.

21. Gentili A. The advanced imaging of gouty tophi. Curr Rheumatol Rep 2006;8:231-5.

22. Chowalloor PV, Keen HI. A systematic review of ultrasonography in gout and asymptomatic hyperuricaemia. Ann Rheum Dis 2013;72:638-45.

23. Gutierrez M, Schmidt WA, Thiele RG, Keen HI, Kaeley GS, Naredo E, et al. International Consensus for ultrasound lesions in gout: results of Delphi process and web-reliability exercise. Rheumatology (Oxford) 2015;54:1797-805.

24. Scirocco C, Rutigliano IM, Finucci A, Iagnocco A. Musculoskeletal ultrasonography in gout. Med Ultrason 2015;17:535-40.

25. Poh YJ, Dalbeth N, Doyle A, McQueen FM. Magnetic resonance imaging bone edema is not a major feature of gout unless there is concomitant osteomyelitis: 10-year findings from a high-prevalence population. J Rheumatol 2011;38:2475-81. 